\title{
DOCÊNCIA NA EDUCAÇÃO INFANTIL: DESAFIOS DIANTE DE COMPORTAMENTOS AGRESSIVOS DAS CRIANÇAS
}

\section{TEACHING IN CHILD EDUCATION: CHALLENGES IN FACE OF AGGRESSIVE BEHAVIORS BY CHILDREN}

\author{
Walquíria Souza Euzébio ${ }^{1}$ \\ Universidade Federal de Minas Gerais \\ Iza Rodrigues Luz ${ }^{2}$ \\ Universidade Federal de Minas Gerais
}

\begin{abstract}
Resumo: Este artigo tem como foco as ações de professoras da Educação Infantil diante de comportamentos das crianças, considerados agressivos. O referencial teórico, conjuga estudos da Educação, Educação Infantil e Psicanálise com destaque para a teoria de Winnicott sobre a agressividade. A pesquisa foi realizada com cinco professoras e 36 crianças da Educação Infantil, de uma Escola Municipal de Belo Horizonte/MG. Através da observação participante e entrevistas semiestruturadas identificamos que para essas professoras os comportamentos agressivos das crianças se apresentavam como ações de morder, bater, empurrar, gritar, fazer "birra", dizer palavras hostis e/ou instigar o colega a agir/falar agressivamente. Como resposta a essas ações as professoras ameaçavam e castigavam as crianças. Argumentamos aqui que uma compreensão não moralista e mais ampliada da agressividade é um dos possíveis caminhos para a construção de outras práticas educativas que incluam também o acolhimento às crianças.
\end{abstract}

Palavras-chave: docência; educação infantil; agressividade.

\begin{abstract}
This article focuses on teachers' actions in face of children so considered aggressive behaviors. Theoretical framework, which main author is Winnicott's concept of aggression, combines studies on Education and Psychoanalysis. The research was carried out with 5 teachers and 36 children from a Community Preschool Education in Belo Horizonte / MG. Through participant observation and semistructured interviews we identified that, for the teachers, children's aggressive behaviors were actions such as biting, hitting, pushing, shouting, making a tantrum, saying hostile words and / or instigating the colleague to act or speak aggressively. In response to these actions, teachers threatened and punished children. We argue here, that recognizing aggression as constitutive is one of possible paths for childcare practices.
\end{abstract}

Keywords: teaching; child education; aggression

\footnotetext{
${ }^{1}$ Mestre em Educação pela Universidade Federal de Minas Gerais (UFMG), professora do ensino fundamental. EMAIL: walquiriadesouza@gmail.com.

2 Doutora em Educação pela Universidade Federal de Minas Gerais (UFMG), professora associada da Faculdade de Educação da Universidade Federal de Minas Gerais (FaE/UFMG) e do Programa de Pós-graduação em Educação. EMAIL: izarodriguesluz@gmail.com. ORCID: https://orcid.org/0000-0002-4772-1329

Revista Tópicos Educacionais, Pernambuco, v. 27, n. 01, p. 79-97, 2021. ISSN: 2448-0215.

https://periodicos.ufpe.br/revistas/topicoseducacionais/index

Dossiê "Conflitos, violências, bullying na escola: problemas da convivência potencializado pela pandemia?" DOI: 10.51359/2448-0215.2021.250376
} 


\section{Por que falar sobre agressividade?}

Este artigo apresenta parte dos resultados de uma pesquisa de mestrado realizada em 2017 e 2018 na qual investigamos as ações de professoras da Educação Infantil diante de comportamentos das crianças, por elas considerados como agressivos. A pesquisa qualitativa, realizada em uma Escola Municipal de Educação Infantil - EMEI, de Belo Horizonte - MG, teve também como sujeitos as 36 crianças de quatro e cinco anos de idade da instituição. Como parte do processo de construção dos dados optamos por articular observação participante e entrevistas semi-estruturadas. As entrevistadas foram seis professoras, sendo que duas delas estavam na função de coordenação e uma na de vice-direção. As entrevistas tiveram como objetivo contemplar os diversos olhares sobre o fenômeno da agressividade e das relações que ali se estabeleceram e ampliar a compreensão da pesquisadora sobre as ações observadas. As análises do material foram orientadas pela questão inicial: "Em que se baseiam as ações das professoras frente a manifestações da agressividade em crianças da Educação Infantil?". Para isto, a partir dos dados produzidos em campo, dialogamos com os estudos das áreas da Educação, da Educação Infantil e da Psicanálise.

Procuramos observar como o assim considerado "comportamento agressivo" é acolhido e entendido pelas professoras, visto que a maioria das pesquisas encontradas por nós direcionaram o olhar para as crianças consideradas agressivas e não, especificamente, para as ações e o papel das professoras frente às situações que exigem uma mediação.

Para compreender esse fenômeno tivemos como aporte teórico os estudos de Donald Woods Winnicott (1987), pediatra e psicanalista inglês. Para ele, a agressividade pode ser vista da seguinte forma: "por um lado, constitui direta ou indiretamente uma reação à frustração. Por outro lado, é uma das muitas fontes de energia de um indivíduo" (WINNICOTT, 2012 [1987], p. 102). A diferenciação de violência $\mathrm{x}$ agressividade é um dos primeiros passos para a compreensão da segunda como parte constitutiva da subjetividade (WINNICOTT, 1987). Na visão do autor a violência tem fins destrutivos, com intenção de prejuízo ao outro; e a agressividade constitui uma tendência presente desde o nascimento, que pode ser expressa com as características da violência, mas é muito mais ampla, sendo vista como constitutiva e impulsionadora de nossas ações criativas.

Corroborando com essa perspectiva buscamos pesquisas que também tiveram como foco a compreensão da agressividade e de sua importância para a constituição do sujeito. Em um estudo sobre a agressividade em psicanálise realizado por Pietro e Jaeger (2008), elas verificaram que "cada vez que a criança agride, mais espera que, dessa forma, seja vista e entendida" (p. 223).

Revista Tópicos Educacionais, Pernambuco, v. 27, n. 01, p. 79-97, 2021. ISSN: 2448-0215. https://periodicos.ufpe.br/revistas/topicoseducacionais/index Dossiê "Conflitos, violências, bullying na escola: problemas da convivência potencializado pela pandemia?" DOI: $10.51359 / 2448-0215.2021 .250376$ 
Defendem, ainda, que "a agressividade só deve ser tratada como um desvio de conduta quando aparece por um longo período de tempo e, também, se não houver fatos transitórios que possam causar comportamentos agressivos" (PIETRO e JAEGER, 2008, p.232). Já Ferrari (2006), apresenta uma definição de agressividade baseada nos conceitos de Freud e Lacan: "a agressividade é vista como constitutiva do eu na sua relação com seus objetos". Para a autora "existe a agressividade, mas ela pode ser sublimada, pode ser recalcada, não precisa ser atuada, pois o humano conta com o recurso da palavra, da mediação simbólica” (FERRARI, 2006, p. 51). Para Luz (2008), tendo como referência os conceitos de Winnicott, a agressividade é um comportamento presente em todas as pessoas e não deve ser visto como algo negativo, ou a ser eliminado.

Ao se compreender o que essas autoras consideram como agressividade e a partir das bases teóricas que as levaram a chegar às suas conclusões, percebe-se a relevância deste trabalho no sentido de dialogar com as produções do campo e contribuir para uma compreensão mais ampliada da agressividade.

\section{A agressividade como ferramenta analítica para a docência na Educação Infantil}

Para Winnicott, o sujeito saudável é aquele que consegue se expressar de maneira criativa e espontânea e, para que isso ocorra, é necessário um ambiente suficientemente bom, "que sobreviva às tentativas e investidas de destruição desse sujeito em seu "processo de maturação"”. Em seus artigos selecionados para compor o livro Privação e Delinquência (2012), o autor afirma que "de todas as tendências humanas, a agressividade, em especial, é escondida, disfarçada, desviada, atribuída a agentes externos e, quando se manifesta é sempre uma tarefa difícil identificar suas origens" (WINNICOTT, 2012, p. 94).

O autor apresenta uma nova perspectiva ao afirmar que a agressão, em suas raízes, é algo inato, que coexiste com o amor. Na agressividade, amor e ódio estão intimamente relacionados, e ela pode se manifestar como um sintoma de medo, ou uma dentre outras maneiras de estabelecer o “que é e o que não é o eu (self)" (WINNICOTT, 2012, p. 89). Sendo assim, um dos indicadores de saúde psíquica é a brincadeira. Uma criança saudável é aquela que consegue brincar sozinha, com seus pares e/ou com adultos. Já a criança desajustada é "aquela para quem o mundo não logrou ajustar-se apropriadamente no início e nas primeiras fases da vida do bebê" (WINNICOTT, 1987, p. 120). Percebe-se mais uma vez a importância dada ao meio social e às brincadeiras na tentativa

Revista Tópicos Educacionais, Pernambuco, v. 27, n. 01, p. 79-97, 2021. ISSN: 2448-0215. https://periodicos.ufpe.br/revistas/topicoseducacionais/index Dossiê "Conflitos, violências, bullying na escola: problemas da convivência potencializado pela pandemia?" DOI: $10.51359 / 2448-0215.2021 .250376$ 
de ajudar a criança a se ajustar ao seu mundo.

\begin{abstract}
Estimulemos a capacidade de brincar da criança. Se uma criança estiver brincando, haverá lugar para um sintoma ou dois, e se ela gostar de brincar, tanto sozinha como na companhia de outras crianças, não há qualquer problema grave à vista. (...). Suas brincadeiras revelam que essa criança é capaz, dado um ambiente razoavelmente bom e estável, de desenvolver um modo de vida pessoal e, finalmente, converter-se num ser humano integral, desejado como tal e favoravelmente acolhido pelo mundo em geral (WINNICOTT, 1987, p. 147).
\end{abstract}

Entendemos que nas brincadeiras as crianças se expressam e tentam compreender o mundo em que vivem. Assim, fantasias com certo grau de agressividade também precisam ser acolhidas e compreendidas pelos adultos. $\mathrm{O}$ autor reforça que um bom ambiente é aquele "capaz de tolerar os sentimentos agressivos, se estes forem expressos de uma forma mais ou menos aceitável" (WINNICOTT, 1987, p. 120), e defende que, quando a criança não pode se expressar de diversas formas ela pode sentir que está sendo desonesta por ter de esconder essa agressividade tendo em vista que nem todos os comportamentos são acolhidos, compreendidos ou aceitáveis.

É importante que a criança expresse o sentimento agressivo não só quando estiver irritada, mas também durante as brincadeiras - mesmo que isso cause desconforto para os adultos que observam esta criança. As crianças não brincam somente por prazer, mas também "para dominar angústias, controlar ideias ou impulsos que conduzem à angústia se não forem dominados" (WINNICOTT, 1987, p. 162).

Outros estudiosos já constataram que as brincadeiras de repetição são uma das formas que as crianças encontram para lidar com sentimentos que não compreendem. Luz (2005), por exemplo, explica que "com o início da capacidade simbólica a criança pode prescindir da realização concreta da destruição e se sentir aliviada com suas fantasias destrutivas, conseguindo através dos sonhos e das brincadeiras dar vazão a sua agressividade” (LUZ, 2005, p. 17).

Nesse sentido, como poderemos conhecer e entender os sentidos da agressividade nas relações das professoras frente a comportamentos considerados agressivos? Alguns estudos (majoritariamente na área da Psicologia e desenvolvidos em ambientes escolares) apresentam dados que podem lançar luz a essa questão.

Os resultados de estudos realizados com professoras e professores indicam que a agressividade, na visão destes sujeitos, é um comportamento a ser evitado e que as maneiras de tratar a questão no ambiente escolar são pouco claras e efetivas tanto para as professoras quanto para as crianças. (LUZ, 2005, SILVA, 2006; SOUZA e CASTRO, 2008; PIETRO e

Revista Tópicos Educacionais, Pernambuco, v. 27, n. 01, p. 79-97, 2021. ISSN: 2448-0215. https://periodicos.ufpe.br/revistas/topicoseducacionais/index Dossiê "Conflitos, violências, bullying na escola: problemas da convivência potencializado pela pandemia?" DOI: $10.51359 / 2448-0215.2021 .250376$ 
JAEGER, 2008; STOLFI, 2009, PICADO e ROSE, 2009; SOUZA, 2012 e GOMES et al, 2012, GAGLIOTO, 2012; STRADA, 2013; CANDREVA, 2015).

$\mathrm{Na}$ pesquisa realizada por Souza e Castro (2008) foi observado que, para os docentes investigados, a agressividade é vista como algo a ser trabalhado com as crianças, mas que esse comportamento é visto como manifestação de rebeldia, falta de limites, estrutura familiar deficiente e, geralmente se apresenta de forma física, como bater e chutar, e de forma verbal, com a intenção de ofender ou magoar o outro. (SOUZA e CASTRO, 2008).

Nesse sentido, Luz (2005) aponta que talvez um dos maiores desafios a ser enfrentado, quando examinamos o fenômeno da agressividade infantil, seja o da aceitação dos adultos de que tal agressividade não é algo ruim, sendo uma das formas de expressão da criança, e que, no lugar de ser reprimida, é necessário auxiliar a criança a encontrar formas de canalizá-la (LUZ, 2005, p. 93). Assim, para além de compreendermos e considerarmos o contexto sociocultural, a trajetória de vida e as experiências profissionais das professoras, é importante considerarmos que uma concepção negativa e moralista da agressividade dificulta a ação junto às crianças. Com uma compreensão mais ampliada da temática, as professoras poderiam auxiliar as crianças, de modo mais adequado, para compreenderem o que estão vivenciando e encontrarem estratégias para se expressarem sem prejudicar a si mesmas e as outras pessoas. Ao contrário, como informado anteriormente, os estudos indicam uma compreensão restrita da agressividade por parte das professoras, como algo ruim e que isso não se relaciona com o que ocorre na escola. Diante disso encontram-se motivos para marginalizar a criança que age de forma agressiva e/ou rotulá-la como “criança problema". A análise dos resultados encontrados nos incentivou a avançar na compreensão da agressividade no campo da educação.

\section{A pesquisa e suas participantes}

O estudo que deu origem ao presente artigo seguiu todas as exigências éticas, tendo sido aprovado pelo Comitê de Ética em Pesquisa - COEP da universidade das autoras, antes do início da pesquisa empírica. Ressalta-se, inclusive, que foi feita a devolução das entrevistas transcritas às professoras, para que pudessem autorizar o uso das informações conforme apresentadas na transcrição, ou modificar e até mesmo retirar algum trecho.

No primeiro encontro com as professoras foi possível perceber certo receio quanto ao fato de a pesquisa ser sobre/com as professoras e não sobre/com as crianças. Por isso, procurou-se

Revista Tópicos Educacionais, Pernambuco, v. 27, n. 01, p. 79-97, 2021. ISSN: 2448-0215. https://periodicos.ufpe.br/revistas/topicoseducacionais/index Dossiê "Conflitos, violências, bullying na escola: problemas da convivência potencializado pela pandemia?" DOI: $10.51359 / 2448-0215.2021 .250376$ 
solucionar quaisquer dúvidas sobre os objetivos e finalidades da pesquisa. Apresentamos a forma como pretendíamos conduzir o processo investigativo e garantimos que suas identidades e também das crianças seriam preservadas no anonimato. Assim, todos os nomes apresentados nesta pesquisa são fictícios. Após aquele primeiro encontro, sentimos que as professoras ficaram menos apreensivas quanto à presença da pesquisadora. No entanto, somente com o passar dos dias e através da relação que foi estabelecida é que as professoras passaram a demonstrar que estavam à vontade com a presença da pesquisadora na escola.

As entrevistas foram incluídas na metodologia com o objetivo de identificar as concepções das professoras sobre o conceito de agressividade, a familiaridade que poderiam ter com a temática e como isso poderia influenciar a forma como lidavam com essas questões nas práticas docentes. Foram utilizados, como referência, dois roteiros de entrevistas. Um para as professoras e outro para as coordenadoras e vice-diretora. Após a realização das entrevistas, fizemos as transcrições das falas e, nesse processo, incluímos as observações e análises das vivências no campo. Em seguida categorizamos todas as ações que tinham relação com a temática investigada.

As professoras que participaram da pesquisa possuíam um perfil diversificado com relação à idade e ao tempo de trabalho na Educação Infantil. Tarsila (26 anos), Pedagoga, Pós-Graduada em Neurociências, acompanhava a Turma A, composta por 16 crianças de quatro anos de idade, seis meninas e 10 meninos. Marta (48 anos) Pedagoga, Pós-Graduada em Educação Infantil e Maria (45 anos), Normal Superior, compartilhavam a docência na turma B, composta por 20 crianças, sendo 12 meninas e 08 meninos de cinco anos de idade. Para as entrevistas contamos ainda com a contribuição de duas coordenadoras, Dandara e Anita, e da vice-diretora, Elza.

Elaboramos algumas categorias para quantificar as ações das professoras e qualificá-las em conjunto na busca por identificar ações que foram recorrentes bem como analisar ações eventuais ou mesmo isoladas de forma reflexiva e compreensiva.

Sabe-se que essa postura requer constante exercício de autorreflexão, tanto pessoal como profissional, por parte das(os) pesquisadoras(es), pois, como identifica o escritor C. S. Lewis (1960/2017) "nunca deveríamos adotar uma atitude prematuramente moral ou avaliadora. De modo geral, a mente humana está muito mais propensa a louvar e depreciar do que a descrever e definir. Deseja fazer de toda a distinção uma distinção de valor” (LEWIS, 2017, p. 25). Assim, durante o tempo naquela instituição buscamos como prática constante a observação, a análise e a

Revista Tópicos Educacionais, Pernambuco, v. 27, n. 01, p. 79-97, 2021. ISSN: 2448-0215. https://periodicos.ufpe.br/revistas/topicoseducacionais/index Dossiê "Conflitos, violências, bullying na escola: problemas da convivência potencializado pela pandemia?" DOI: $10.51359 / 2448-0215.2021 .250376$ 
descrição das ações docentes e das respostas das entrevistadas, evitando qualquer tipo de julgamento.

\section{A agressividade na visão das professoras}

"É uma coisa já podada. A criança é agressiva, chama a atenção, ela perde a vez, eu converso com a família, eu mando pra coordenação. Pronto! Aí depois eu falo assim: "não tem jeito" (Entrevista, professora Tarsila, 2017).

Esse trecho de uma das entrevistas sintetizou o que observamos - tanto em campo quanto nas entrevistas - ser a prática mais recorrente das professoras quando as crianças se comportavam de maneira considerada inadequada. No momento em que as professoras presenciavam comportamentos indesejáveis, elas chamavam a atenção da criança, normalmente falando que não deveriam ter agido de determinada forma, e em seguida as crianças eram castigadas ou enviadas para a coordenação que, caso considerasse necessário, entrava em contato com as famílias.

Ao perguntamos às professoras o que consideravam ser agressividade, elas exemplificavam com episódios nos quais a agressividade se manifestava. Para a professora Marta a agressividade, na maioria das vezes, acontecia por "falta de limites" e eram os familiares os responsáveis por ensinar como as crianças deveriam se expressar:

Alguns têm problema mesmo, alguma síndrome, alguma coisa, mas a maioria é falta de limite. Tá acostumado a fazer em casa, os pais não corrigem e... acham que podem fazer na escola. Eu acho que a maioria é isso. Alguns, sim, [...] têm alguns transtornos, alguma coisa, mas a grande maioria é falta de limite. (Entrevista, Professora Marta, 2017).

Para Marta, a agressividade poderia ser um tipo de patologia ou de indisciplina e que, portanto, deveria ser uma questão a ser resolvida pela família. Já para a professora Maria, a agressividade era uma estratégia que as crianças usavam para se proteger de algo ou alguém ou para demonstrar que estavam insatisfeitas com alguma situação cotidiana: "É até um meio de se proteger né, por isso que ela agride. Não só fisicamente, mas ofendendo, fazendo uma birra... é uma agressão.... uma pirraça... aquilo é uma forma de agressão também” (Entrevista, Professora Maria, 2017). Ao pedirmos que explicasse ações que considerava agressivas, Maria exemplificou citando momentos em que as crianças empurravam os colegas, ou arrastavam os colegas: "assim, não pensa na consequência... que tá machucando o colega, só simplesmente vai lá e... bate, dá rasteira, e joga assim...” (Entrevista, Professora Maria, 2017).

Para a professora Tarsila as crianças são agressivas "quando batem, mordem ou empurram. Quando a criança, pra ela chegar a algum objetivo, ela tem que usar disso, sabe, de uma palavra pejorativa ou de um gesto, de um toque de forma mais agressiva" (Entrevista, Professora Tarsila, Revista Tópicos Educacionais, Pernambuco, v. 27, n. 01, p. 79-97, 2021. ISSN: 2448-0215. https://periodicos.ufpe.br/revistas/topicoseducacionais/index Dossiê "Conflitos, violências, bullying na escola: problemas da convivência potencializado pela pandemia?" DOI: $10.51359 / 2448-0215.2021 .250376$ 
2017). Para ela a agressividade era uma das formas que as crianças utilizavam para alcançar seus objetivos e que isso não era uma característica positiva.

Para as entrevistadas, talvez o único ponto positivo da agressividade fosse mostrar que alguma coisa "fora do normal” estava acontecendo com aquela criança.

\begin{abstract}
Pelo menos é um alerta né? Porque, às vezes, em casa, a mãe não percebeu isso, né? Que a criança está agressiva. E acontecendo isso aqui, a gente vai chamar a família para que ela procure ajuda ou dialogue com a criança... porque... ela tá gritando, né, porque se ela tá sendo agressiva alguma coisa tá acontecendo em casa, não é normal você sair assim... do nada, agredindo os colegas, o professor... (Entrevista, Professora Maria, 2017).

O comportamento sim... eu acho que é ruim, mas a leitura não. Eu acho positiva a estratégia, mas eu acho negativa a expressão. Porque no lugar de empurrar talvez ele pudesse falar: "me dá licença, por favor." E aí essa é positiva (Entrevista, Professora Tarsila, 2017).

Olha... nem sempre... acho que é uma fase que a criança está passando, mas que ela vai vencer. Mas quando a criança tem essa dificuldade, aí se torna um comportamento ruim. Não é para professor, ele até pode ter um trabalho danado com essa criança, mas o pior é para a criança, porque ela acaba dificultando a socialização dela com as outras crianças. Se a gente não tiver um cuidado muito grande, essa criança fica excluída (Entrevista, Professora Elza, 2017).

Dandara: Não! Eu acho que às vezes é o tipo da agressividade é pra chamar a atenção, ou pedir socorro, então eu acho que é uma agressividade positiva, você entendeu? Se ela está batendo muito no colega, se você for lá, na pontinha do iceberg, você vai ver que essa criança tá apanhando muito também (Entrevista, Professora Dandara, 2017).
\end{abstract}

Através das falas das entrevistadas, identificamos que as professoras construíram concepções sobre agressividade a partir de suas vivências e práticas cotidianas e entendiam que o comportamento dos adultos influenciava no modo como as crianças agiam. Algumas a consideravam como um comportamento a ser eliminado, outras como sinônimo de violência ou indisciplina e que as crianças agiam de maneira agressiva especialmente quando estavam passando por algum problema no ambiente familiar ou escolar. Acreditavam que, como as crianças estavam aprendendo a se expressar através da fala, elas se faziam entender por meio de ações, e que algumas desenvolviam comportamentos considerados agressivos como uma forma de "pedir ajuda" ou mostrar que algo não estava bem. Com relação ao que consideravam ações agressivas, as professoras descreveram: dizer palavras hostis, morder, bater, empurrar, gritar, fazer "birra" ou instigar o colega a agir agressivamente. Endossando a concepção dessas professoras, Bispo e Lima (2014) apontam que conforme uma pesquisa feita em serviços de saúde, muitas crianças são enviadas para atendimento devido a comportamentos considerados violentos.

A maior parte das queixas por problemas de comportamento relacionados à escola é por agressividade/nervosismo $(35,5 \%)$ e dificuldade de socialização $(17,8 \%)$. Esse aumento considerável de encaminhamentos de crianças para os serviços de saúde com queixas de comportamentos violentos e/ou agressivos aponta para a necessidade de se considerar a relação desse fenômeno com a instituição escolar. (BISPO E LIMA, p. 167, 2014)

Revista Tópicos Educacionais, Pernambuco, v. 27, n. 01, p. 79-97, 2021. ISSN: 2448-0215.

https://periodicos.ufpe.br/revistas/topicoseducacionais/index

Dossiê "Conflitos, violências, bullying na escola: problemas da convivência potencializado pela pandemia?" DOI: $10.51359 / 2448-0215.2021 .250376$ 
Esta pesquisa, assim como outras da área da educação (ARREGUY, ARROYO, 2007), apontam a violência ou agressividade como um dos principais problemas enfrentados nas escolas. Então, após identificarmos o que consideravam serem atitudes agressivas, indagamos às entrevistadas sobre como agiam quando as crianças tinham comportamentos considerados agressivos. Trazemos abaixo um trecho da entrevista com uma das professoras:

\begin{abstract}
Pesquisadora: Como você age em situações como essa? Você recebeu alguma orientação sobre como agir nesse tipo de situação, algum documento ou orientação da coordenação ou da direção?

Tarsila: Não. Foi observação mesmo da prática. Eu não tirei isso de nenhum livro. Eu tirei isso da prática. Eu nunca li um livro sobre agressividade, não é um tema que me chama muito a atenção. Até mesmo porque já tem um preconceito: se o menino é agressivo já é uma coisa de casa... você tem que conversar com a família... é o que a gente pratica na escola. Mas eu sei que é importante saber, assim como é importante saber das metodologias. Mas eles priorizam... na universidade eles priorizam. É melhor você saber metodologia de Língua Portuguesa, Matemática, do que você entender... saber lá das fases do conhecimento, do que você entender dessa parte... dessa expressão da criança, porque é tratado como uma criança que não sabe e tem que aprender. Aí você conversa com a família e remedia, mas entender o porquê, as estratégias... isso não tem muito não. É uma coisa já podada: a criança é agressiva, chama a atenção, ela perde a vez, eu converso com a família, eu mando pra coordenação, pronto. Aí depois eu falo assim: não tem jeito! Mas eu tenho muita vontade de aprender um pouco mais sobre esse assunto, porque a gente lida com ele o tempo todo. As crianças não têm maturidade de lidar com os conflitos e elas são agressivas, aí a gente tem que saber mais sobre isso (Entrevista, Professora Tarsila, 2017).
\end{abstract}

Neste trecho, observamos que, no pouco tempo que tivemos para refletir sobre as ações com a professora Tarsila, ela demonstrou, uma ampliação de concepção com relação às próprias ações e pensamentos. Ela começou seu discurso seguindo uma linha de pensamento que se desdobrou para a reflexão e o reconhecimento da necessidade de compreender o fenômeno da agressividade. Neste momento constatamos parte daquilo que os estudos da área da Educação (CORDEIRO, 2018; BITENCOURT, 2020, LOMBA, 2020) têm apontado sobre a necessidade de oferecer às professoras da Educação Infantil oportunidades de formação continuada para que ampliem o conhecimento sobre o desenvolvimento infantil e possam refletir sobre suas próprias práticas.

Para auxiliar as crianças a compreenderem as consequências de suas ações, as professoras afirmaram que pediam aos pequenos para se colocarem no lugar do(a) colega que foi machucado(a), ou seja, tentavam estimular nas crianças atitudes empáticas. Outras ações que as docentes disseram usar como ferramentas eram os castigos, conversas e bilhetes destinados às famílias.

Revista Tópicos Educacionais, Pernambuco, v. 27, n. 01, p. 79-97, 2021. ISSN: 2448-0215. https://periodicos.ufpe.br/revistas/topicoseducacionais/index Dossiê "Conflitos, violências, bullying na escola: problemas da convivência potencializado pela pandemia?" DOI: $10.51359 / 2448-0215.2021 .250376$ 


\section{Ampliando o conceito de agressividade - análises das entrevistas}

Rotineiramente, as punições eram as consequências das ações consideradas inapropriadas. Punições carregadas de "violência velada" por parte das professoras, infelizmente não eram casos raros. Essa observação nos levou a identificar que as pesquisas precisam trabalhar de forma mais sistemática com métodos de observação de campo no sentido de ajudar a ampliar o olhar sobre as ações das docentes. Grande parte dos trabalhos encontrados sobre a relação das professoras com as crianças recorrem apenas às entrevistas com as professoras, deixando de contemplar as vivências docentes no campo e, assim, estabelecerem relações entre as concepções apresentadas pelas professoras e suas ações no cotidiano com as crianças.

As entrevistas evidenciaram que as educadoras se sentem impotentes e, muitas vezes, despreparadas para intervir de forma adequada perante comportamentos que consideram problemáticos ou inadequados. Sabe-se que retirar as crianças do convívio com seus pares não é uma ação adequada ou efetiva e que seria importante que as professoras tivessem o apoio necessário para refletirem sobre isso e também para tratarem dos problemas que surgem no cotidiano sem que para isso se desgastassem física e emocionalmente. Nesse sentido Castro e Souza (2012) percebem que as professoras, muitas vezes, se auto culpabilizam, "como se o fracasso no manejo dos conflitos constituísse uma falha pessoal, despertando desânimo, solidão e abatimento" (CASTRO E SOUZA, 2012, p. 268).

A partir dos elementos apresentados, defendemos a ampliação do conceito de agressividade, de modo que se reconheça a diferença entre a agressividade relacionada à motilidade, como "algo próprio da criança, e a agressividade hostil, voltada para a destruição do outro ou de objetos, e que essa ampliação possa subsidiar outras formas de conduzir a ação educativa" (LUZ, 2005, p. 99).

\section{1. As ações das professoras diante de manifestações de agressividade das crianças}

Ao longo da pesquisa observamos que, de modo geral, as professoras puniam as crianças por seus comportamentos considerados inadequados, sem esclarecerem os motivos dos castigos, ameaças ou punições. Presenciamos apenas algumas situações nas quais as crianças eram orientadas sobre como agirem frente às frustrações. Para a coordenadora Dandara, não havia "agressividade nas crianças, mas sim, uma agressividade velada - que seria mais das professoras para com as

Revista Tópicos Educacionais, Pernambuco, v. 27, n. 01, p. 79-97, 2021. ISSN: 2448-0215. https://periodicos.ufpe.br/revistas/topicoseducacionais/index Dossiê "Conflitos, violências, bullying na escola: problemas da convivência potencializado pela pandemia?" DOI: $10.51359 / 2448-0215.2021 .250376$ 
Revista Tópicos Educacionais

Revista do Programa de Pós-Graduação em Educação

da Universidade Federal de Pernambuco (UFPE)

crianças.” (Entrevista, Professora Dandara, 2017). Essa mesma percepção encontramos em outros trabalhos relacionados à temática. Gonçalves endossa que:

Em nossos dias, ao se falar sobre esse tema, há uma forte tendência de vê-lo como algo que parte exclusivamente dos alunos, de seus conflitos com os professores, da agressão física que os envolve, da presença de drogas nas escolas, de armas de fogo, e assim por diante. Mas é preciso deixar bem claro que a história da violência no ambiente escolar é antiga, e o fenômeno, muito mais difundido do que se imagina. (GONÇALVES, 2010, p. $3)$.

Admitir que a violência escolar parte de um contexto social e está presente nas ações dos adultos nas instituições é um passo importante para pensarmos em estratégias de transformação da realidade. Pensando nisso, criamos um gráfico com todas as ações que tivemos oportunidade de presenciar no campo, a fim de compreender como as professoras agiram frente a ações consideradas inadequadas. E nos propomos a refletir sobre elas:

Gráfico 1: Ações das professoras diante de manifestações de agressividade das crianças

\section{AÇÕES DAS PROFESSORAS}

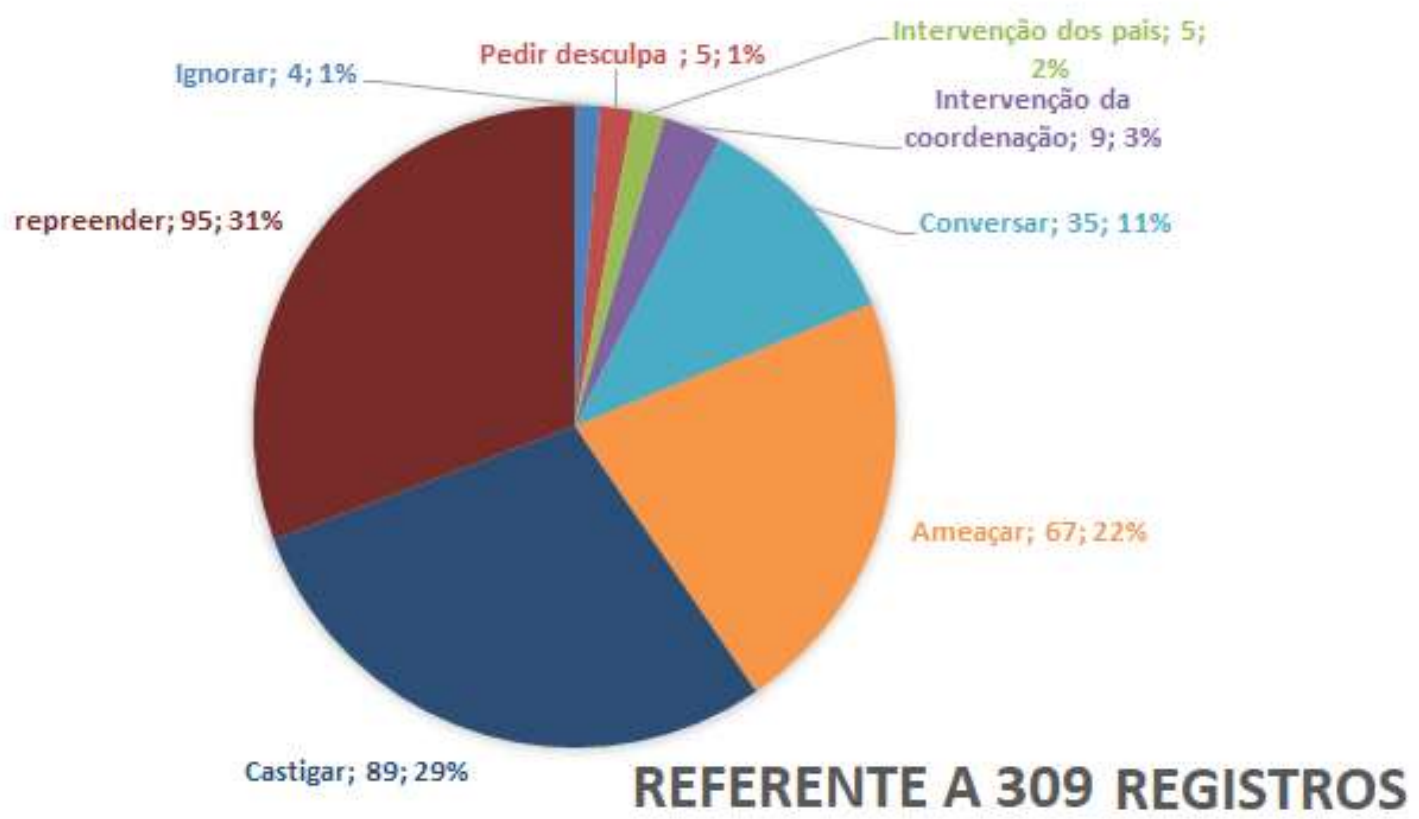

Fonte: Arquivos da Pesquisa, 2017.

As ações das professoras foram divididas em oito categorias e, a partir dessa organização,

observamos que, na maior parte das vezes em que as professoras presenciaram ações consideradas Revista Tópicos Educacionais, Pernambuco, v. 27, n. 01, p. 79-97, 2021. ISSN: 2448-0215.

https://periodicos.ufpe.br/revistas/topicoseducacionais/index

Dossiê "Conflitos, violências, bullying na escola: problemas da convivência potencializado pela pandemia?" DOI: $10.51359 / 2448-0215.2021 .250376$ 
inadequadas, elas repreendiam as crianças (31\%). Essas repreensões eram muitas vezes seguidas de castigos $(29 \%)$ ou de ameaças $(22 \%)$.

$\mathrm{Na}$ sessão abaixo exemplificamos como as repreensões eram seguidas de algum castigo e em seguida como as repreensões eram seguidas de ameaças. Posteriormente mostraremos o que presenciamos quando as professoras conversavam com as crianças.

\section{Repreensões seguidas de castigo:}

Marta (professora): Raiane, você perdeu a vez. Acabaram as suas chances. Vem aqui ficar em pé. De frente pra mim (ela fica assim por volta de 4 minutos).

Tarsila (professora): Que coisa vocês dois com essa brincadeira! Estão cansados de saber que não podem brincar de bater. Eu não quero vocês dois perto. Cansei. Rafael você vai perder a vez. Por que os bagunceiros sempre gostam de ficar juntos? Eu não mereço, não. Eu não aguento e não mereço. (as crianças são separadas das demais e ficam sentadas em um cantinho da sala).

Maria (professora): A professora gritando diz que vai buscar Pedro pra ele aprender a subir direito no brinquedo. Ela o traz arrastado pelo braço e o obriga a ser o último da fila como forma de punição; ele não aceita o castigo e tenta resistir. Ela o empurra para a parede e com o dedo indicador contra seu peito diz que ele tem que aprender a obedecer e que ela não aguenta mais ele. (apesar de resistir por um tempo, Pedro acaba ficando no último lugar da fila). (Diário de Campo, 2017).

A violência em meio escolar ainda hoje está presente por meio dos castigos aplicados pelas professoras. Resquícios de um modelo de educação fundamentado em práticas de punições físicas e humilhações - antes legitimadas socialmente- ainda estão presentes (GONÇALVES, 2010). O autor lamenta que "o mais dramático em todas essas possíveis cenas de humilhação é o fato de que nós, professores, podemos praticar atos ofensivos sem termos consciência de que eles são violentos". (p.3). Mesmo com todos os estudos na área da Educação Infantil que apontam para uma educação que tenha a criança como centro do processo educativo e que proíba quaisquer formas de violência (BRASIL, 2009; LUZ, 2010) percebemos que não há um preparo sistemático e prático para eliminar tais ações.

Nandy (2015), dialogando com o pensador social DeMause, apresenta uma questão importante, mas de difícil aceitação. Para eles, as crianças continuam sendo maltratadas, como sempre foram ao longo da história, e "que o mundo moderno, no mínimo, é um pouco mais gentil com a criança” (NANDY, 2015, p. 231). O autor argumenta que no mundo moderno a violência tradicional se converteu em violência institucionalizada.

Essa violência institucionalizada que durante muito tempo perpassou a esfera física se modificou com a proibição dos castigos físicos exigindo que nossa atenção agora seja voltada para Revista Tópicos Educacionais, Pernambuco, v. 27, n. 01, p. 79-97, 2021. ISSN: 2448-0215. https://periodicos.ufpe.br/revistas/topicoseducacionais/index Dossiê "Conflitos, violências, bullying na escola: problemas da convivência potencializado pela pandemia?" DOI: $10.51359 / 2448-0215.2021 .250376$ 
a violência simbólica. Bispo e Lima (2014) tratam dessa violência ao descreverem esse comportamento nas instituições escolares e afirmam que:

Há uma violência que se institucionaliza e se organiza em dispositivos simbólicos, como na própria lei e nos aparelhos repressivos do Estado. Essa violência permanece velada, mas se coloca como necessária para manter o funcionamento da ordem cultural, de modo a ser socialmente legitimada. Surge, assim, um aparato simbólico coercitivo que servirá para inibir as desordens. O resultado é que temos, de um lado, uma violência supostamente legítima, não apenas apoiada nas instituições sociais, mas por elas exercida; e, de outro, uma violência ilegítima, praticada por aqueles que resistem à ordem, colocando-se como uma ameaça ao poder vigente. (BISPO E LIMA, p. 168, 2014)

Para Nandy (2015) a "violência institucionalizada" são as diversas formas de exploração social e psicológica das crianças, que não são vítimas apenas de seus pais, mas também da sociedade.

\begin{abstract}
(...) Elas [as crianças] são vítimas da falta de sentido do colapso da mutualidade entre gerações, do individualismo sem limites (...) elas são vítimas de uma visão de mundo que vê a criança como uma versão inferior, fraca, mas utilizável, do ser humano plenamente operacional que é dono do mundo moderno (NANDY, 2015, p. 233).
\end{abstract}

No entanto, e mesmo com as cenas presenciadas no campo, reconhecemos que essa visão tem, a passos lentos, se modificado. Através de inúmeros estudos que vêm sendo desenvolvidos ao longo das últimas décadas, compreende-se que as crianças devem ser valorizadas no presente e não na sua função social futura (ALMEIDA, 2009; GOUVÊA E SARMENTO, 2008). As crianças não são seres incompletos que precisam de auxílio para atingir a máxima do ser adulto. No entanto, a forma como as crianças têm sido tratadas evidencia o quanto precisamos avançar.

Todas as formas de "castigos institucionalizados" que observamos foram usados pelas professoras como estratégia de contenção física das crianças. Castigos como deixar algumas crianças em pé ou sentada na frente da sala, tirar os brinquedos ou deixar sem parquinho, foram as punições mais utilizadas durante o tempo que estivemos em campo.

\footnotetext{
Marta: Você quer ficar em pé? Então vai ficar em pé!

(Coloca-o em pé, na frente da sala, enquanto explica a atividade de para casa. Pedro, mesmo em pé, dá um jeito de se mexer e isso deixa a professora irritada).

Pedro: Professora, deixa eu brincar?! Eu não vou mais bater.

Maria: Tem que pensar antes de bater. Agora vai ficar aí. (Estavam no parquinho).

Tarsila entra apressada na sala da Marta e coloca Francisco sentado no chão.

Tarsila: Senta aí! Batendo nos amigos! (Sai da sala deixando Francisco sentado no chão da sala da professora Marta. Todas as crianças olham para a criança que demonstra vergonha).
}

Revista Tópicos Educacionais, Pernambuco, v. 27, n. 01, p. 79-97, 2021. ISSN: 2448-0215.

https://periodicos.ufpe.br/revistas/topicoseducacionais/index

Dossiê "Conflitos, violências, bullying na escola: problemas da convivência potencializado pela pandemia?" DOI: $10.51359 / 2448-0215.2021 .250376$ 
Revista Tópicos Educacionais

Revista do Programa de Pós-Graduação em Educação

da Universidade Federal de Pernambuco (UFPE)

(Diário de Campo, 2017).

Percebemos que nessas ações não havia espaço para diálogos permitindo que as professoras explicassem às crianças o que haviam feito de errado, ou oportunidades para apresentarem novas formas de se expressarem. Vimos que essa lacuna gerava um visível esgotamento físico e emocional tanto nas professoras como nas crianças, pois elas não se faziam entender e as ações indesejadas das crianças continuavam a ocorrer.

Iza e Mello (2009) identificaram algo semelhante em suas pesquisas:

As professoras têm grande desgaste em fazer com que as crianças fiquem quietas e caladas e, ao mesmo tempo, isso acarreta um prejuízo para a criança, pois a creche passa a ter o significado de um lugar onde ela deve conter-se sempre, ficar em silêncio, obedecer sem questionar e, no qual suas ideias, seus gostos, suas opiniões e reflexões não podem ser considerados. As crianças deixam de ter oportunidades de aprender novos conhecimentos de maneira prazerosa. (IZA e MELLO, p. 197, 2009)

O exemplo a seguir evidencia essa falta de comunicação. Em uma situação, quando a professora Tarsila determinou que uma das crianças tinha "perdido a vez" e lhe ordenou "sentar de castigo" perto de onde estava a pesquisadora, esta aproveitou o momento para perguntar à criança por que tinha "perdido a vez". Para nossa surpresa, a criança perguntou "que vez?". Percebemos que aquela criança não sabia o que a expressão "perder a vez" significava. Claro, aos poucos, no cotidiano escolar, ela aprenderia que isso significava ficar de castigo, fora da brincadeira ou atividade. No entanto, esse episódio nos ajudou a compreender que nem sempre o que está claro para o adulto está claro para as crianças.

No caso dessa criança, ela não sabia o que significava "perder a vez" e talvez nem soubesse por que fora retirado da rodinha. Portanto, nessa situação, a ação da professora não auxiliou a criança na compreensão da inadequação de seu comportamento. Compreender que o processo de compreensão das regras pelas crianças deve ser parte do trabalho pedagógico na Educação Infantil pode auxiliar na construção de práticas que possibilitem a relevância de que sejam pactuadas (o que nas escolas geralmente se denomina "combinados"), e reforçadas ao longo do dia. Deixar claro os objetivos para cada atividade realizada com as crianças e o que se espera delas é fundamental neste processo.

Os dados apresentados apontam que, em geral, os adultos não dão o devido respeito à singularidade da infância visto que não reconhecem as crianças como sujeitos de desejos e pensamentos próprios. Ainda hoje a violência é utilizada como principal forma de punir e educar.

Revista Tópicos Educacionais, Pernambuco, v. 27, n. 01, p. 79-97, 2021. ISSN: 2448-0215. https://periodicos.ufpe.br/revistas/topicoseducacionais/index Dossiê "Conflitos, violências, bullying na escola: problemas da convivência potencializado pela pandemia?" DOI: $10.51359 / 2448-0215.2021 .250376$ 


\section{Revista Tópicos Educacionais}

As professoras investigadas usaram a violência sem se constranger com a presença da pesquisadora, provavelmente por sequer se questionarem sobre a pertinência de suas ações. Se considerassem por algum momento que determinada atitude seria considerada violenta, discriminatória ou até ilegal, provavelmente não fariam, ou não repetiriam, tais ações na presença da pesquisadora ou de outros adultos - e é isto que Nandy (2015) - como vimos acima - chama de "violência institucionalizada".

Corroborando com as reflexões feitas por Nandy (2015), Pino (2007) destaca que no Brasil a situação relacionada à violência não é muito diferente. Ele relaciona a violência como um vírus que penetra o tecido social e causa adoecimento moral das instituições. Para ele, o fenômeno da violência não é novo nem exclusivo do Brasil, no entanto, as formas com que ela se apresenta são inusitadas e suas consequências imprevisíveis (p. 764). Ele argumenta que para legitimar a violência surge uma racionalidade cheia de "razões" para ultrapassar os limites das regras próprias da razão humana.

A criança, como sujeito de direitos frequenta as instituições escolares para se socializar e aprender a dialogar com seus pares. Ter como base o respeito entre adultos e crianças faz parte daquilo pelo qual o campo da educação vem lutando ao longo do tempo através de ações e pesquisas.

\section{Repreensões seguidas de ameaça}

Marta (professora): Deixa eu ver quem está gritando pra fazer companhia para o Pedro. É a Raiane? Quem tá correndo, hein? Eu mandei correr? Foi você sim que eu vi! Mateus, no seu lugar.

Tarsila (professora): Rafael, você está dando conta? Ou quer perder a vez?

Maria (professora): A Raiane te bateu? Eu vou contar para a mãe dela.

(Diário de Campo, 2017).

Comumente, quando chamavam a atenção das crianças, as professoras deixavam de explicar os motivos que as levavam a fazer essas ameaças ou aplicar os castigos. Tivemos poucas oportunidades, durante nosso período no campo, de observar momentos nos quais as professoras explicaram às crianças em que elas "erraram", tampouco situações nas quais pudessem refletir juntas sobre as ações consideradas inadequadas. Nas ameaças observamos a manutenção de uma educação tradicional/violência institucionalizada que tinha a repressão como forma de controle dos

Revista Tópicos Educacionais, Pernambuco, v. 27, n. 01, p. 79-97, 2021. ISSN: 2448-0215. https://periodicos.ufpe.br/revistas/topicoseducacionais/index Dossiê "Conflitos, violências, bullying na escola: problemas da convivência potencializado pela pandemia?" DOI: $10.51359 / 2448-0215.2021 .250376$ 
corpos e a disciplina como algo a ser implementado a qualquer custo. $\mathrm{Na}$ entrevista com a professora Tarsila, ela deu a seguinte definição para o que considerava ser indisciplina:

Indisciplina a gente analisa de acordo com o que a gente quer, né? É o que o professor quer no momento. Então, se eu quero que os meninos fiquem sentados, quietos, respirando, e eles não fazem isso, então eu falo que é indisciplina. (Tarsila, Entrevista, 2017).

Quando as professoras apenas ameaçavam as crianças, observei que o resultado mais provável era fazer a criança parar o que estava fazendo de "errado" momentaneamente e apenas por medo de que a ameaça se concretizasse. Como podemos ver a seguir:

Marta: Eu já falei que eu quero filmar ele fazendo isso para mostrar pros pais dele (Pedro apontou o dedo do meio para as professoras). Ele não senta direito, né?! Tem que voltar para o berçário para aprender a sentar.

Maria: A Raiane te bateu? Eu vou contar para a mãe dela.

Tarsila: Você não vai mais brincar com os brinquedos da escola, porque você quebra tudo! (Rafael tinha jogado o carrinho no chão e a rodinha tinha caído). Pode pegar a roda e você vai consertar, pois foi você quem quebrou (ele encaixa a roda). Você quebra brinquedos na sua casa. Aqui na escola não! (Diário de Campo, 2017).

Nos momentos em que pudemos observar as professoras ameaçando as crianças, percebemos que estas não compreendiam os motivos de não poderem agir como estavam agindo. Muitas vezes esperavam que a professora se distraísse para continuar fazendo aquilo que as levara a serem ameaçadas.

\section{Conversar com as crianças}

Nos momentos em que as professoras optaram por conversar com as crianças - mesmo quando essas "conversas" não contemplavam um diálogo (só a professora falava) - foi possível observar que os pequenos demoravam mais para voltar a fazer o que era considerado indesejável pelas professoras; nesses momentos as crianças pareciam compreender melhor as consequências de suas ações.

Marta conversa com as crianças e pede que respeitem a professora Maria durante os momentos do jantar e que se comportem do mesmo jeito que se comportam quando estão com Marta.

Antes de irem para o lanche, a professora Maria pede que todas as crianças se sentem no corredor para repassar as regras e reafirmar o comportamento que espera deles no refeitório. As crianças ouvem com atenção e em seguida todos se dirigem para o refeitório. (Diário de Campo, 2017).

Revista Tópicos Educacionais, Pernambuco, v. 27, n. 01, p. 79-97, 2021. ISSN: 2448-0215.

https://periodicos.ufpe.br/revistas/topicoseducacionais/index

Dossiê "Conflitos, violências, bullying na escola: problemas da convivência potencializado pela pandemia?" DOI: $10.51359 / 2448-0215.2021 .250376$ 


\section{Revista Tópicos Educacionais}

As cenas presenciadas acima condizem com os direitos de aprendizagem e desenvolvimento das crianças, descritos dentro dos seis pilares propostos pela BNCC, que permitem às crianças aprenderem "em situações nas quais possam desempenhar um papel ativo em ambientes que as convidem a vivenciar desafios e a sentirem-se provocadas a resolvê-los" (BRASIL, 2018, p.37).

\section{Algumas considerações}

O olhar de distanciamento privilegiado de pesquisadora, permitiu observar que vários acontecimentos rotineiros e simples que causavam grande estresse e cansaço para as professoras poderiam ser resolvidos se as crianças também fossem incluídas e informadas das intenções que as professoras tinham para determinados momentos/objetos/espaços.

Para as professoras, a agressividade era expressa pelas crianças quando estas usavam palavras hostis, mordidas ou brigas entre os colegas; quando empurravam, gritavam, faziam birra ou instigavam outros colegas a agirem da mesma forma. Considerando a visão de Winnicott (2012) sobre a importância de um ambiente favorável, que suporte as manifestações de agressividade das crianças, acreditamos que uma ampliação na compreensão da temática poderia auxiliar as escolas a se constituírem em contextos com essa qualidade. Sem esse reconhecimento, aumenta-se a possibilidade de as crianças serem seriamente repreendidas sem que tenham condições de compreender melhor as relações que constroem com as outras pessoas e consigo mesmas.

A falta de compreensão sobre a importância da expressão de agressividade é um grande limitador das possibilidades de ação tanto das professoras quanto das crianças. No entanto, observamos que as docentes que participaram da pesquisa não possuíam condições de trabalho que lhes permitissem refletir sobre essas questões. O silenciamento sobre temas como agressividade e violência; e a falta de oportunidades para debater e refletir sobre suas ações diante de comportamentos das crianças que consideravam inadequados contribuíram para que as contradições entre as falas/reflexões e ações das profissionais permanecessem ocultas e, de certa maneira, contribuíram também para que as professoras se sentissem desamparadas.

Quando as crianças tinham comportamentos que não condiziam com a expectativa das professoras, elas eram deliberadamente punidas. Entendemos que a motivação das professoras para

Revista Tópicos Educacionais, Pernambuco, v. 27, n. 01, p. 79-97, 2021. ISSN: 2448-0215. https://periodicos.ufpe.br/revistas/topicoseducacionais/index Dossiê "Conflitos, violências, bullying na escola: problemas da convivência potencializado pela pandemia?" DOI: $10.51359 / 2448-0215.2021 .250376$ 
agirem frente a manifestações que consideravam agressivas eram suas experiências de prática moldadas por um modelo de disciplina escolar em que as crianças devem ser silenciadas.

$\mathrm{Na}$ docência, como em tantas outras profissões, o reconhecimento e a valorização profissional influenciam diretamente na atuação. Nesse sentido, consideramos importante o acompanhamento desses profissionais, tanto no aspecto pedagógico quanto psicológico. Esse suporte se mostra fundamental, especialmente nas mediações de conflitos, já que as professoras não precisam "dar conta de tudo sozinhas", mas tampouco podem se esquivar de sua responsabilidade frente ao cuidado e educação das crianças. É importante trabalhar no sentido de orientar as professoras na mediação dos comportamentos agressivos, de forma a canalizar essa força para que se apresente como construtiva na expressão das crianças e não como uma tentativa de eliminá-la.

Acreditamos que o conceito de agressividade na perspectiva winnicottiana poderia ser incorporado no universo escolar. Ter momentos e espaços para refletir sobre as práticas frente aos comportamentos inesperados das crianças, se apresenta como a principal estratégia. Nesse sentido, indicamos a promoção de momentos de reflexão entre professoras e coordenadoras para juntas desenvolverem estratégias de ação que possam auxiliar as crianças e as professoras na expressão da agressividade e no desenvolvimento dos relacionamentos. Consideramos que vivemos em um contexto social que legitima práticas violentas e compreende a agressividade como algo negativo; portanto, é necessário ter maior reflexão sobre como - enquanto sujeito individual e coletivo temos vivenciado nossa própria agressividade.

A visão moralista sobre a agressividade impede que ela seja vivenciada e, portanto, que seja compreendida e/ou aceita. Como vimos, um ambiente favorável, que suporte as manifestações de agressividade das crianças é fortemente defendido por Winnicott por acreditar que esse tipo de ambiente contribui para a constituição de indivíduos saudáveis e para o fortalecimento da autonomia.

Cabe a nós, educadoras, refletirmos sobre essa realidade, a fim de compreendê-la, primeiramente em nós mesmas e depois para auxiliar as crianças e famílias com as quais convivemos e por quem somos responsáveis. Para isso, um olhar atento das professoras e demais profissionais da escola somado aos relacionamentos de qualidade com as famílias podem auxiliar na compreensão dos diversos contextos nos quais as crianças vivem e dar sentido às suas ações cotidianas.

Revista Tópicos Educacionais, Pernambuco, v. 27, n. 01, p. 79-97, 2021. ISSN: 2448-0215. https://periodicos.ufpe.br/revistas/topicoseducacionais/index Dossiê "Conflitos, violências, bullying na escola: problemas da convivência potencializado pela pandemia?" DOI: $10.51359 / 2448-0215.2021 .250376$ 


\section{Referências bibliográficas}

ALMEIDA, Ana Maria. Para uma sociologia da infância. Instituto de Ciências Sociais, Lisboa: 2009.

ARREGUY, M. E.; MORENA-TORRES, M.; CAMPOREZ, G. A. Violência simbólica e fracasso escolar: reflexões psicanalíticas na educação. RevistAleph, Rio de Janeiro, ano VI, n.17, p.53-70, jul. 2012.

ARROYO, Miguel G. Quando a violência infantojuvenil indaga a pedagogia. Revista Educação e Sociedade. Campinas, v.28, n.100, p.787-807, maio/ago. 2007.

BISPO, Fábio Santos; LIMA, Nádia Laguárdia. A violência no contexto escolar: uma leitura interdisciplinar. Educação em Revista. Belo Horizonte. V.30, n2, p. 161-180. Abril/junho. 2014.

BITENCOURT, Lais Caroline Andrade. Docência com bebês: experiências sociais e dimensão sensorial no trabalho de professoras e auxiliar no cuidado e educação de bebês em uma Instituição de Educação Infantil. Tese (Doutorado em Educação). Universidade Federal de Minas Gerais: Belo Horizonte, 2020)

BRASIL. Ministério da Educação. Base Nacional Comum Curricular. Brasília, 2018.

CANDREVA, T; et al. A agressividade na educação infantil: o jogo como forma de intervenção. Pensar a Prática, v. 12, n. 1, abr. 2009.

CORDEIRO, Regina Coele. Formação Continuada das Professoras da Educação Infantil: ações do município de Montes Claros / MG. Dissertação (Mestrado em Educação). Universidade Federal de Minas Gerais: Belo Horizonte, 2018.

EUZÉBIO, Walquíria de Souza. Percepções e ações de professoras diante das manifestações de agressividade das crianças em uma instituição de Educação Infantil. Dissertação (Mestrado em Educação). Universidade Federal de Minas Gerais: Belo Horizonte, 2018.

FERRARI, I. F. Agressividade e Violência. Revista Psicologia Clínica, Rio de Janeiro, vol.18, n. 2, p. 49-62. 2006. GAGLIOTTO, G.M.; BERTÉ, R.; VALE, G.V. Agressividade da criança no espaço escolar: uma abordagem psicanalítica. Revista Reflexão e Ação, Santa Cruz do Sul, v.20, n. 1, p. 144- 160, jan./jun.2012.GARCIA. Roseana Moraes. A Agressividade na Psicanálise Winnicotiana. Tese (Doutorado em Psicologia Clínica). Pontifícia Universidade Católica de São Paulo. São Paulo, 2009.

GOUVEA, Maria Cristina Soares; SARMENTO, Manuel (orgs.) Estudos da Infância: educação e práticas sociais. Petrópolis: Vozes, 2008.

GONÇALVES, Luiz Alberto Oliveira. Diálogo com docentes acerca da violência em meio escolar. Anais do I Seminário Nacional: Currículo em Movimento - Perspectivas Atuais Belo Horizonte, novembro de 2010.

IZA, Dijnane Fernanda Vedovatto; MELLO, Maria Aparecida. Quietas e caladas: as atividades de movimento com as crianças na Educação Infantil. Educação em Revista. Belo Horizonte. v.25, n.02, p.283-302, ago. 2009.

LEWIS. C. S. Os Quatro Amores. $1^{\text {a }}$ ed. - Rio de Janeiro: Thomas Nelson Brasil, 2017.LUZ, Iza. Agressividade na Primeira Infância: Um estudo a partir das relações estabelecidas pelas crianças no ambiente familiar e na creche. Tese. (Doutorado em Educação) Universidade Federal de Minas Gerais: Belo Horizonte, 2005.

LOMBA. Maria Lúcia de Resende. Docência na Educação Infantil: percursos de vida, formação e condições institucionais das experiências de professoras no cuidado e educação

Revista Tópicos Educacionais, Pernambuco, v. 27, n. 01, p. 79-97, 2021. ISSN: 2448-0215.

https://periodicos.ufpe.br/revistas/topicoseducacionais/index

Dossiê "Conflitos, violências, bullying na escola: problemas da convivência potencializado pela pandemia?" DOI: 10.51359/2448-0215.2021.250376 
de crianças de 4 e 5 anos. Tese (Doutorado em Educação). Universidade Federal de Minas Gerais: Belo Horizonte, 2020. NANDY, Ashis. A Imaginação Emancipatória: Desafios do Século 21; Belo Horizonte: Editora UFMG, 2015.

PREFEITURA MUNICIPAL DE BELO HORIZONTE. MELO, Ana Cláudia Figueiredo Brasil Silva (org). Proposições Curriculares para a Educação Infantil: eixos estruturadores. Desafios da Formação, Volume 2. 190 p. Belo Horizonte: SMED, 2015.

PICADO, J. R; ROSE, T. M. S. Acompanhamento de pré-escolares agressivos: adaptação na escola e relação professor-aluno. Psicol. cienc. prof. 2009, vol.29, n.1, pp.132-145.

PIETRO, Patrícia Pereira; JAEGER, Fernanda Pires. Agressividade na infância: análise psicanalítica. Joaçaba Visão Global, v. 11, n. 2, jul./dez. 2008.

PINO. A. Violência, Educação e Sociedade: Um olhar sobre o Brasil Contemporâneo. Educação e Sociedade, Campinas, vol. 28, nº 100 - Especial, p. 763-785, out/ 2007.

SILVA, D.R. Agressividade em crianças: um estudo em contexto educacional préescolar. Dissertação (Mestrado em Psicologia), Programa de Pós-Graduação em Psicologia da Educação, Pontifícia Universidade Católica de São Paulo. São Paulo, SP.

SOUZA, Carolina Duarte de; Caracterização da agressividade entre pares de crianças, por professoras pré-escolares. Dissertação (Mestrado em Psicologia). Florianópolis, 2012.

SOUZA, Maria Abigail de; CASTRO Rebeca Eugênia Fernandes de. Agressividade infantil no ambiente escolar: concepções e atitudes do professor. Maringá, Psicologia em Estudo,v. 13, n. 4, p. 837-845, out./dez. 2008.

STRADA, N.T.; GONÇALVES, G.M.S. Agressividade na Educação Infantil. Diálogos Educacionais em Revista, Campo Grande, MS, v. 4, n. 2, p.107-122, dez. 2013. STOLFI, Paula Furine. Concepções de professores sobre agressão e violência em crianças no início da escolarização. Dissertação (mestrado) - Universidade Estadual Paulista, Faculdade de Ciências e Letras, Araraquara, 2009.

WINNICOTT, Donald Woods. Agressão e suas raízes - raízes da agressão. Rio de Janeiro: Martins Fontes, 1987.

WINNICOTT, Donald Woods. Privação e delinquência. São Paulo: Martins Fontes, 2012.

Recebido em abril de 2021.

Aprovado em junho de 2021.

Revista Tópicos Educacionais, Pernambuco, v. 27, n. 01, p. 79-97, 2021. ISSN: 2448-0215.

https://periodicos.ufpe.br/revistas/topicoseducacionais/index

Dossiê "Conflitos, violências, bullying na escola: problemas da convivência potencializado pela pandemia?" DOI: 10.51359/2448-0215.2021.250376 